\title{
Rumen-protected methionine a feed supplement to low dietary protein: effects on microbial population, gases production and fermentation characteristics
}

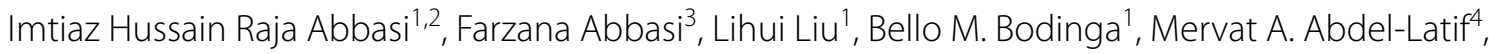
Ayman A. Swelum ${ }^{5}$ (D), Mohamed Abdalla Elsiddig Mohamed ${ }^{1}$ and Yangchun Cao ${ }^{{ }^{*}}$

\begin{abstract}
The present study was performed to evaluate the effects of different concentration of rumen-protected methionine (RPMet) with a low level of crude protein (CP) using rumen simulation technology on many parameters. The experiment was assigned randomly into four treatments: (1) high protein diet (163.39 g/kg CP) without RPMet (HP); (2) low protein diet (146.33 g/kg CP) without RPMet (LP); (3) low protein diet, supplement with low RPMet (RPMet: $0.11 \mathrm{~g} / \mathrm{kg}$ ) (LPLMet); and (4) low protein diet, supplement with high RPMet (RPMet: $0.81 \mathrm{~g} / \mathrm{kg}$ ) (LPHMet), mixed with $20 \mathrm{~g}$ basal diet in each fermenter. Based on National Research Council (NRC) (Nutrient requirements of dairy cattle, National Academies Press, Washington, DC, 2001) recommendation for dairy ruminants HP diet was formulated as positive normal control and LP as a negative control. Results demonstrated that CP disappearance was found significantly higher $(P<0.05)$ in supplement groups compared with HP and found similar $(P>0.05)$ with LP. However, neutral detergent fiber (NDF) and gross energy (GE) were found a parallel among supplement groups compared to HP and higher than LP. Furthermore, microbial crude protein, total and short chain fatty acids were found similar in LPHMet and HP and found significantly higher than LPLMet and LP. The R. albus population of LPHMet found parallel to HP and pointedly higher than LP in a solid and liquid fraction. Daily production of ammonia nitrogen, total gas, and methane were higher in HP than LP, LPLMet, and LPHMet. Overall, results concluded that values of digestibility, rumen fermentation, microbial crude protein, and R. albus population were similar of LPHMet to that of HP group. However, production of ammonia-N, total gas, and methane volume were significantly higher in the HP group than LPLMet, LPHMet, and LP groups. In conclusion, rumen-protected methionine is a good feed supplement to low dietary protein in the level of $0.81 \mathrm{~g} / \mathrm{kg}$.
\end{abstract}

Keywords: Dietary protein, Feed degradability, Fermentation, Rumen-protected methionine, Rumen simulation

\section{Introduction}

Rumen environment quickly degrades free amino acids (AA) and could not maintain the performance of dairy ruminants. The ruminants obtain AA mainly from two sources microbial protein and rumen undegradable protein (RUP) that is washed to the abomasum and appear

\footnotetext{
*Correspondence: caoyangchun@126.com

${ }^{1}$ College of Animal Science and Technology, Northwest A\&F University, Yangling, Shaanxi, China

Full list of author information is available at the end of the article
}

to meet the maintenance needs of ruminants, these both play a significant role to keep the balance of metabolizable protein (MP) of ruminants. These sources must be absorbed as free AA from the small intestine of ruminants (Faciola and Broderick 2014). Rumen-protected methionine (RPMet) known as top limiting essential AA for ruminants, particularly in those where milk is sold not only for volume but also for the component values (Vasconcelos et al. 2007; Abbasi et al. 2018a). Its supplementation could improve the AA balance of MCP and consequentially reduce the deamination of absorbed 
AA and decrease blood urea nitrogen which is valuable for the reproduction and performance of dairy animals (Rhoads et al. 2006). Increasing the level of limiting amino acids in the small intestine, resulting in increasing milk volume, protein, fat yields and reduces urine nitrogen (Zhang et al. 2013; Abbasi et al. 2017). Amino acids balance is considered as the most significant factor compared to the supplementation of total rumen degradable protein (RDP) for improving the nitrogen utilization. Limiting AA flow particularly methionine in the small intestine is considered the essential element for milk yield and milk protein production (Noftsger et al. 2005). It became a growing objective to reduce crude protein $(\mathrm{CP})$ in animal diets, with the supplementation of rumen-protected limiting amino acids to raise the quantity of MP as it increases AA flow in the small intestine. And decrease nitrogen losses, feed cost and global environmental pollution, without adverse impact on animal performance (Sinclair et al. 2014; Guyader et al. 2016).

Therefore, it is imperative to evaluate and compare the effects of supplementation of RPMet systematically with low dietary protein diet in modulating ruminal fermentation. To this end, the current study was to determine the degree to which level RPMet supplementation could replace low protein diet concerning their effects on rumen fermentation, nutrients metabolism, gases production, microbial protein synthesis and specific bacterial population using rumen simulation technique (RUSITEC). Because, high dietary CP not only increase the heat increment with energy loss but also led to environmental problems; with "low CP diet+RPMet" feed cost, energy losses, as well as nitrogen losses can be decreased.

\section{Materials and methods}

\section{Experimental apparatus and description of the test product}

The experiment was carried out using a rumen simulation technique (RUSITEC, Sanshin, Tokyo, Japan) as described by Kajikawa et al. (2003). The test product was provided as mepron ${ }^{\circledR}$ is a rumen-protected DLmethionine $85.00 \%$ (CAS-RN: 59-51-8; DL-methionine) and rumen bypass rate was $80.00 \%$ developed by Evonik (Germany Industries AG, health, and nutrition feed additives Rodenbacher Chaussee 4-63457 Hanau-Wolfgang).

\section{Donor animals and experimental diets}

Three healthy Xinong Saanen goats [average initial body weight $(50.63 \pm 1.20 \mathrm{~kg})$ ], were housed in pens and the same basal RUSITEC diet offered as a total mixed ration to animals at 07:00 and 19:00 with free access to water. Rumen contents were collected through the ruminal fistula before the morning feeding and placed into thermos flasks pre-heated at $39{ }^{\circ} \mathrm{C}$ by filling with hot water and quickly transferred to the laboratory. The experiment was randomly designed and conducted over two independents 15 days incubation periods with 7 days for adaption and 8 days for samples collection. The four groups were: (1) high protein without RPMet (HP, $163.39 \mathrm{~g} / \mathrm{kg} \mathrm{CP}$ ), (2) low protein without RPMet (LP, $146.33 \mathrm{~g} / \mathrm{kg} \mathrm{CP}$ ), (3) low protein $(141.80 \mathrm{~g} / \mathrm{kg} \mathrm{CP})$ supplemented with low concentration of RPMet $(0.11 \mathrm{~g} / \mathrm{kg} \mathrm{DM})$ (LPLMet), and (4) low protein $(143.30 \mathrm{~g} / \mathrm{kg} \mathrm{CP})$ supplemented with a high concentration of RPMet $(0.81 \mathrm{~g} / \mathrm{kg}$ DM) (LPHMet). Based on NRC (2001) recommendation of CP for dairy cows, HP diet was formulated as a positive control, LP as a negative control group. The chemical compositions of experimental diets were similar among all treatments without out $\mathrm{CP}$ percentage, and other formulated values are represented in Table 1.

\section{Experimental procedure and sampling}

After collection of rumen inoculum, the inoculum was mixed, strained through four layers of cheesecloth maintained anaerobic condition. Incubation was started as described Zhao et al. (2010). On day 1st each fermenter was filled with $350 \mathrm{~mL}$ strained liquid inoculum with $350 \mathrm{~mL}$ of artificial saliva solution as described by McDougall (1948). One nylon bag containing $70 \pm 0.05 \mathrm{~g}$ of solid rumen digesta (wet weight basis) as inoculum and one nylon bag of an experimental diet comprising roughages and concentrates (45:55 DM, basis) weighted $20 \pm 0.04 \mathrm{~g}$. To increase the chewing activity of ruminants the roughages and concentrates ingredients was grounded to pass through ( 4 and $2 \mathrm{~mm}$ ) sieves respectively. To maintained and improve the flow of microbes in fermenters, the size of nylon bags was selected $18 \times 9 \mathrm{~cm}$ with a pore size of $100 \mu \mathrm{m}$. To maximize the ruminal peristalsis and increase ruminant's salivation secretion, each fermenter in vertical position were agitated at 2 cycles/min and artificial saliva (McDougal's) was freshly prepared and infused continuously into each fermenter by precision pump guaranteed at a rate of approximately $2.85 \% / \mathrm{h}$ directed by Kajikawa et al. (2003). After $24 \mathrm{~h}$ solid inoculum bag was replaced with a new feed bag. On subsequent days, the old bag $48 \mathrm{~h}$ replaced with new one. Consequently, each bag incubated in its fermenter for $48 \mathrm{~h}$ and the $\mathrm{CO}_{2}$ flush was maintained during the entire process. After the adaption period, on days 8,9 , and 10 , the $5 \mathrm{~mL}$ fluid was subsampled from each fermenter to determined $\mathrm{pH}$ immediately before exchanging the feed bags. Three litter Tedlar bags were put into the inlet of each fermenter and closed with a plastic screw to collect gas during $24 \mathrm{~h}$ from RUSITEC fermentation to determine the concentration of methane, hydrogen, and carbon dioxide gases production. After 
Table 1 Ingredients and chemical composition of diets offered to animals and used in RUSITEC experiment (dry matter basis)

\begin{tabular}{|c|c|c|c|c|c|c|}
\hline \multirow[t]{2}{*}{ Items } & \multicolumn{4}{|c|}{ Treatments } & \multirow[t]{2}{*}{ SEM } & \multirow[t]{2}{*}{ P-value } \\
\hline & HP & LP & LPLMet & LPHMet & & \\
\hline \multicolumn{7}{|l|}{ Ingredients, g/kg dry matter } \\
\hline Corn silage & 182.40 & 193.60 & 193.60 & 193.50 & & \\
\hline Alfalfa hay & 101.60 & 39.20 & 39.20 & 39.20 & & \\
\hline Wheat straw & 153.00 & 213.80 & 213.70 & 213.60 & & \\
\hline Ground corn & 162.30 & 216.50 & 216.50 & 216.40 & & \\
\hline Wheat bran & 77.80 & 46.80 & 46.80 & 46.70 & & \\
\hline Soybean meal & 70.30 & 100.50 & 100.50 & 100.40 & & \\
\hline Cottonseed meal & 96.20 & 38.20 & 38.20 & 38.20 & & \\
\hline Corn germ meal & 115.50 & 105.60 & 105.60 & 105.60 & & \\
\hline Limestone & 10.50 & 8.80 & 8.80 & 8.80 & & \\
\hline Di calcium phosphate & 0.00 & 4.80 & 4.80 & 4.80 & & \\
\hline Sodium chloride & 10.50 & 12.00 & 12.00 & 12.00 & & \\
\hline Sodium bicarbonate & 1.90 & 2.00 & 2.00 & 2.00 & & \\
\hline Premix* & 18.00 & 18.10 & 18.10 & 18.00 & & \\
\hline RPMet & 0.00 & 0.00 & 0.11 & 0.81 & & \\
\hline \multicolumn{7}{|l|}{ Chemical composition } \\
\hline Dry matter (g/kg DM) & 902.50 & 890.25 & 892.00 & 893.75 & 5.40 & 0.89 \\
\hline Crude protein (g/kg DM) & $163.39^{\mathrm{a}}$ & $146.33^{b}$ & $141.80^{\mathrm{b}}$ & $143.30^{b}$ & 3.38 & 0.01 \\
\hline Neutral detergent fiber (g/kg DM) & 471.16 & 471.72 & 471.21 & 470.38 & 1.28 & 0.99 \\
\hline Acid detergent fiber (g/kg DM) & 212.12 & 210.87 & 205.37 & 212.27 & 2.04 & 0.70 \\
\hline Ether extract (g/kg DM) & 28.50 & 28.00 & 28.02 & 28.11 & 0.52 & 1.00 \\
\hline Gross energy (MJ/kg DM) & 16.28 & 16.13 & 16.13 & 16.50 & 0.14 & 0.85 \\
\hline
\end{tabular}

SEM, standard error of the mean

a,b Superscripts values within the same row, are significantly different at $(P<0.05)$

* Premix (per kilogram of total-mixed ration, DM basis contains): $10.5 \mathrm{mg} \mathrm{Cu}, 9.80 \mathrm{mg} \mathrm{Zn,} 12.00 \mathrm{mg} \mathrm{Mn}, 0.11 \mathrm{mg}$. Co, $0.32 \mathrm{mg}$ I, $0.15 \mathrm{mg}$ Se, $2500 \mathrm{IU}$ vitamin A, $500 \mathrm{IU}$ vitamin D3, and $40 \mathrm{IU}$ vitamin $\mathrm{E}$

the adoption period, the $20 \mathrm{~mL}$ of $\mathrm{H}_{2} \mathrm{SO}_{4}(3.66 \mathrm{M}, 20 \%$, $\mathrm{V} / \mathrm{V}$ ) was added to each effluent bottle to control further fermentation. The $6 \mathrm{~mL}$ effluent liquid was collected for analysis of volatile fatty acid (VFA) mixed with $1 \mathrm{~mL}$ of $25 \%$ of metaphosphoric acid, and $5 \mathrm{~mL}$ of effluent was preserved to analyze ammonia- $\mathrm{N}\left(\mathrm{NH}_{3}-\mathrm{N}\right)$ concentration and stored under $-20{ }^{\circ} \mathrm{C}$ for analysis. One feed bag (containing residue) from every fermenter was collected, clean with $100 \mathrm{~mL}$ of artificial saliva then washed into the cold rinse cycle for $(10 \mathrm{~min})$ using the washing machine, dried in air forced oven for $24 \mathrm{~h}$ at $65{ }^{\circ} \mathrm{C}$ stored at room temperature for further nutrients disappearance analysis. On 11 days, after replacing the feed bag from each fermenter $6 \mathrm{~mL}$ fluid was collected and $\mathrm{pH}$ was measured immediately at $0,2,4,6,8,12,18$ and $24 \mathrm{~h}$. On 12 and 13 days, $5 \mathrm{~mL}$ of saturated $\mathrm{HgCl}_{2}$ was added to the effluent collection bottles, all bottles were held in an ice bath. On 13 and 14 days, approximately $400 \mathrm{~mL}$ of effluent fluid was collected for isolation of liquid associated microbial mass, and nylon bags contents were preserved for solid associated microbial mass to examine microbial crude protein (MCP) concentration. On day 15, during $24 \mathrm{~h}$ incubation period by the displacement of water, total gas was collected in $3 \mathrm{~L}$ Tedlar bags and gas volume was measured. Additionally, $10 \mathrm{~mL}$ of fermenters fluid as the liquid fraction and one feed bag contents covering undigested feed after $48 \mathrm{~h}$ incubation as the solid portion from each fermenter was freeze-dried for DNA study of total bacteria and specific cellulolytic species analysis.

\section{Laboratory analyses of feed and fermenters samples}

Feed and RUSITEC residue samples were dried at $105^{\circ} \mathrm{C}$ for $24 \mathrm{~h}$ and ground to pass through a $1 \mathrm{~mm}$ screen (Standard model 04, Arthur Thomas, Philadelphia) for further chemical analysis. The CP content was analyzed using micro Kjeldahl (Foss, Dk, 3400 Hillerod, Denmark). Acid detergent fiber (ADF) and neutral detergent fiber (NDF) values were determined as described by VanSoest et al. (1991) with the modified method used with an ankom ${ }^{200}$ fiber analyzer unit (Ankom Technology, 
Macedon, USA). Alpha-amylase (Sigma A-3306, Sigma, Aldrich, China), and sodium sulfite were added to each sample separately for NDF determination. Both ADF and NDF were expressed inclusive of residual ash, and all samples were analyzed in triplicate. Ether extract (EE) was examined by extracting samples with petroleum ether using a Gerhardt Soxtherm-2000 Automatic (AOAC, 1990; id 920.39). Gross energy (GE) of samples was determined by complete oxidation using an adiabatic bomb calorimeter (AC 500, Leco, St. Joseph, and Mi) (Parr Instrument Co, 1970). The dietary RPMet ratio of each ration was estimated based on the included ingredients using the Cornell, Penn-Miner Dairy (CPM, Dairy, and Version 3.0.8.1) Software. The total and individual VFA concentrations of each sample were determined through gas chromatography (Agilent Technology 7820A GC system, Santa Clara, USA) using a $30 \mathrm{~m} \times 0.25 \mathrm{~mm} \times 0.33-\mathrm{m}$ fused silica column (Atech Tech, Co., Ltd. PR, China) followed the procedure of Abbasi et al. (2018b). The concentration of gases was analyzed by gas chromatography (model 663-30, Hitachi Corporation, Tokyo, Japan) equipped with a flame ionization detector according to Lambert and Zitomer (1960). The volume of total gases produced during $24 \mathrm{~h}$ incubation was collected in $3 \mathrm{~L}$ Tedlar bags and measured through calibrated $60 \mathrm{~mL}$ plastic syringe (Dismadel SL, Madrid, Spain) according to Soliva and Hess (2007). MCP concentration was determined according to the modified optical density method Zhang et al. (2015). The $\mathrm{NH}_{3}-\mathrm{N}$ was analyzed by the indophenols method according to Weatherburn (1967). The $\mathrm{pH}$ values before or after feeding were measured immediately using $\mathrm{pH}$ electrode (Mettler, Toledo Ltd, England, and the UK). The nutrients disappearance rate was calculated according to Abbasi et al. (2018b).

The disappearance of DM and other indexes were calculated as $(\mathrm{g} / \mathrm{kg})$

$$
\text { Disappearance }=\left[\left(\mathrm{W}_{3}-\mathrm{W}_{4}\right) / \mathrm{W}_{3}\right] \times 1000
$$

where, $\mathrm{W}_{3}, \% \mathrm{DM}$ in the feed sample $\left[\left(\mathrm{W}_{1}-\mathrm{W}\right) \times \mathrm{DM} \%\right.$; $\mathrm{W}_{4}$, residue $\mathrm{DM}$ weight $\left[\mathrm{W}_{2}-\mathrm{W}\right] \times 100 ; \mathrm{W}$, empty bag weight; $\mathrm{W}_{1}$, the weight of bag with feed sample before incubation; $\mathrm{W}_{2}$, the weight of bag with residue after incubation.

The metagenomic DNA in $4 \mathrm{~mL}$ of the fermenters fluid and $1 \mathrm{~g}$ undigested fermenters feed residue was extracted using a modified (CTAB) method as described by Kumar et al. (2014). The quality of the extracted DNA was detected using $1 \%$ agarose gel by electrophoresis and concentration of DNA was calculated at both absorbance ratio $260 / 280$ and $230 / 260$ by using spectrophotometer (Nano, Drop-2000 Thermo Technology, Inc, DE, USA). For further analysis DNA samples were stored at $-80{ }^{\circ} \mathrm{C}$. The $16 \mathrm{~S}$ rDNA genes copy number was determined through quantitative real-time PCR of cellulolytic specific-species; F. succinogenes, $R$. albus, $R$. flavefaciens and total bacteria. The PCR primer sets were used for amplification of total bacteria, and cellulolytic specificspecies by (Koike and Kobayashi 2001; Schwiertz et al. 2010) were presented in Table 2.

The copy number of each standard plasmid was calculated using as described by $\mathrm{Yu}$ et al. (2005), and the DNA standard calibration curve was made. The $16 \mathrm{~S}$ rDNA copy numbers of cellulolytic species and total bacteria were calculated as by Zhao et al. (2013), and Liu et al. (2017). The real-time PCR was performed on ninety-sixwell optical plates using CFX96TM Bio-Rad-IQ5 PCR System (Bio-Rad, Lab, Inc, Hercules, USA), was used for PCR assays with SYBR Green Dye Premix Ex Taq ${ }^{\mathrm{TM}} \mathrm{II}$ (Takara, Dalian, Liaoning, China). The PCR reaction $(20 \mu \mathrm{L})$ contained $1 \mu \mathrm{L}$ of forward and reverse primers, respectively, $7 \mu \mathrm{L}$ of double standard sterile water, $1 \mu \mathrm{L}$ of $30 \mathrm{ng}$ (tenfold dilutions of $30 \mathrm{ng}$ ) of extracted bacterial genomic DNA, and $10 \mu \mathrm{L}$ of SYBR Premix, Ex, Taq. The different copy numbers and cycle threshold $(\mathrm{Ct})$ values were used to construct species-specific calibration curves. These curves were used for the calculation of DNA copy numbers (Zhao et al. 2013) all samples were examined in triplicate. The gene copy numbers were linearized by $\log _{10}$ before processing for data analysis.

Table 2 Primer sequence used for quantitative real-time PCR analyses

\begin{tabular}{|c|c|c|c|}
\hline Target bacterial species & Forward primer sequence $\left(5^{\prime}-3^{\prime}\right)$ & Reverse primer sequence $\left(5^{\prime}-3^{\prime}\right)$ & $\begin{array}{l}\text { Amplicon } \\
\text { size (bp) }\end{array}$ \\
\hline Total bacteria ${ }^{a}$ & ACTCCTACGGGAGGCAGCAGT & ATTACCGCGGCTGCTGGC & 174 \\
\hline F. succinogenes $^{\mathrm{b}}$ & GGTATGGGATGAGCTTGC & GCCTGCCCCTGAACTATC & 446 \\
\hline R. albus ${ }^{b}$ & CCCTAAAAGCAGTCTTAGTTCG & CСTCCTTGCGGTTAGAACA & 175 \\
\hline R. flavefaciens ${ }^{b}$ & TCTGGAAACGGATGGTA & CCTTTAAGACAGGAGTTTACAA & 295 \\
\hline
\end{tabular}

F. succinogenes, Fibrobacter succinogenes; R. albus, Ruminococcus albus; R. flavefaciens, Ruminococcus flavefaciens

a Schwiertz et al. (2010)

b Koike and Kobayashi (2001) 


\section{Data analyses}

The data of $48 \mathrm{~h}$ incubation of all parameters of every incubation were averaged and each batch fermentation was considered as a replicate. The response variable was analyzed using IBM SPSS version 22.0 (SPSS Inc., Chicago, IL, USA) with treatment as a fixed factor and the incubation period was treated as a random factor. The probability value $(P)$ and standard error of means (SEM) are presented in each Table. Significance was declared at $(\mathrm{P}<0.05)$ and trends were discussed at $(\mathrm{P}<0.10)$ differences among means were tested using Tukey's multiple comparison tests.

\section{Results}

Effect of rumen-protected methionine supplements on the disappearance

The effects of supplements with low protein diet on disappearance indexes incubated $48-\mathrm{h}$ in RUSITEC fermenters are presented in Table 3. Compared with the controls the disappearance of dry matter (DM), ether extract (EE) and acid detergent fiber (ADF) were unaffected by supplements of RPMet different levels $(\mathrm{P}>0.05)$. However, NDF and GE degradation of supplement groups were non-significant to HP positive control, while significantly higher $(\mathrm{P}<0.05)$ to the LP negative control group. Although, $\mathrm{CP}$ disappearance at RUSITEC fermenters was found significantly higher in supplement groups than HP and parallel with LP control groups.

\section{Effect of the supplements on total and individual volatile fatty acids}

The daily productions of total and individual VFA profiles were shown in Table 4. Daily production of acetate, propionate, butyrate (short-chain fatty acids), and the ratio of acetate to propionate were unaffected $(\mathrm{P}>0.05)$ among LPHMet and HP group, but LPLMet was significantly $(\mathrm{P}<0.05)$ lower than HP and similar $(\mathrm{P}>0.05)$ to LP group. Total VFA production was linearly increased in LPHMet compared to LP but parallel to the HP group. Although, the molar proportion of LPLMet supplement

Table 3 Effects of supplementation of rumen-protected methionine with low CP on disappearance using rumen simulation technique $(n=4)$

\begin{tabular}{|c|c|c|c|c|c|c|}
\hline \multirow[t]{2}{*}{ Substrate disappearance } & \multicolumn{4}{|c|}{ Treatments } & \multirow[t]{2}{*}{ SEM } & \multirow[t]{2}{*}{ P-value } \\
\hline & $\mathrm{HP}$ & LP & LPLMet & LPHMet & & \\
\hline Dry matter (g/kg DM) & 693.28 & 696.78 & 692.03 & 700.44 & 11.67 & 1.00 \\
\hline Crude protein (g/kg DM) & $773.94^{b}$ & $815.94^{\mathrm{a}}$ & $824.01^{\mathrm{a}}$ & $832.61^{\mathrm{a}}$ & 7.75 & 0.01 \\
\hline Neutral detergent fiber (g/kg DM) & $612.60^{a}$ & $534.69^{b}$ & $594.54^{\mathrm{a}}$ & $611.40^{\mathrm{a}}$ & 9.85 & $<0.01$ \\
\hline Acid detergent fiber (g/kg DM) & 450.21 & 433.48 & 510.24 & 466.35 & 18.95 & 0.58 \\
\hline Ether extract (g/kg DM) & 809.60 & 827.56 & 838.16 & 833.50 & 12.30 & 0.89 \\
\hline Gross energy (MJ/kg DM) & $667.91^{\mathrm{a}}$ & $602.08^{b}$ & $635.46^{a}$ & $663.74^{\mathrm{a}}$ & 8.72 & $<0.01$ \\
\hline
\end{tabular}

SEM, standard error of mean

$\mathrm{a}, \mathrm{b}$ Superscripts values within the same row, are significantly different at $(P<0.05)$

Table 4 Addition of RPMet with low CP their effects on daily production of total and individual volatile fatty acids using the RUSITEC $(n=4)$

\begin{tabular}{|c|c|c|c|c|c|c|}
\hline \multirow[t]{2}{*}{ Items } & \multicolumn{4}{|c|}{ Treatment } & \multirow[t]{2}{*}{ SEM } & \multirow[t]{2}{*}{ P-value } \\
\hline & $\mathrm{HP}$ & LP & LPLMet & LPHMet & & \\
\hline Total VFA (mM) & $100.17^{a}$ & $87.42^{c}$ & $91.33^{b}$ & $100.47^{a}$ & 1.71 & $<0.01$ \\
\hline Acetate (mM) & $50.74^{a}$ & $45.17^{b}$ & $47.17^{b}$ & $47.78^{a b}$ & 0.35 & $<0.01$ \\
\hline Propionate (mM) & $27.60^{a}$ & $25.50^{b}$ & $25.83^{b}$ & $27.50^{\mathrm{a}}$ & 0.32 & $<0.01$ \\
\hline Isobutyrate (mM) & 0.83 & 0.81 & 0.82 & 0.83 & 0.36 & 0.99 \\
\hline Butyrate (mM) & $13.67^{\mathrm{a}}$ & $10.33^{b}$ & $11.07^{b}$ & $12.91^{\mathrm{a}}$ & 0.45 & $<0.01$ \\
\hline Isovalerate (mM) & 2.97 & 3.03 & 3.06 & 3.07 & 0.18 & 0.99 \\
\hline Valerate (mM) & 4.18 & 3.65 & 3.89 & 4.09 & 0.02 & 0.79 \\
\hline Acetate: propionate ratio & $1.84^{\mathrm{ab}}$ & $1.75^{b}$ & $1.82^{\mathrm{ab}}$ & $1.87^{\mathrm{a}}$ & 0.02 & 0.04 \\
\hline
\end{tabular}

VFA, volatile fatty acids; SEM, standard error of mean

$a, b, c$ Superscripts values within the same row, are significantly different at $(P<0.05)$ 
was significantly higher than LP but lower than the HP group.

\section{Effect of the supplements on rumen $\mathrm{pH}, \mathrm{NH}_{3}-\mathrm{N}$,} and microbial protein synthesis

Effects of RPMet supplements on rumen $\mathrm{pH}, \mathrm{MCP}$ synthesis and $\mathrm{NH}_{3}-\mathrm{N}$ concentration from RUSITEC fermenters are presented in Table 5. The concentration of MCP of LPHMet was $(\mathrm{P}>0.05)$ similar to HP and higher $(\mathrm{P}<0.05)$ than the LP group. However, LPLMet was similar to LP and significantly lower than the HP group. The $\mathrm{NH}_{3}-\mathrm{N}$ production was unaffected $(\mathrm{P}>0.05)$ among supplemented and LP, but it was significantly lower than the HP group. Compared with control groups supplementation of RPMet did not significantly alter rumen $\mathrm{pH}$, the values before and after feeding on 0 to $24 \mathrm{~h}$ were found similar.

\section{Effect of the supplements on total and greenhouse gases production}

Impact of RPMet supplements with low $\mathrm{CP}$ on total gas and greenhouse gases production are presented in Table 6. Production of methane gas was linearly decreased $(\mathrm{P}<0.05)$ in supplemented groups during 24 h RUSITEC incubation than HP, but it was similar to $(\mathrm{P}>0.05)$ LP group. While the volume of other gases; $\mathrm{CO}_{2}$ and $\mathrm{H}_{2}$ was unaffected compared to control groups. However, the total gas volume of HP control was significantly higher than the supplements and LP group.

\section{Effect of the supplements on total and cellulolytic species 16S rDNA gene copy}

The effect of supplements on the 16S rDNA gene copy numbers of total bacteria and cellulolytic species are presented in Table 7. The abundance numbers of $16 \mathrm{~S}$ rDNA gene of cellulolytic species $R$. albus was similar among LPHMet and HP, but higher than the LP group. Whereas, LPLMet values were similar to $(P>0.05) L P$ and significantly lower $(\mathrm{P}<0.05)$ than HP group at RUSITEC fermenters. Furthermore, compared to the control groups the16S rDNA gene copy numbers of total bacteria and other cellulolytic species $F$. succinogene and R. flavefaciens in supplements groups were found unaffected in liquid and a solid fraction at RUSITEC fermenters.

\section{Discussion}

In recent era numerous amino acids patterns for maintenance and production of dairy cows under investigation, the addition of simple AA in ruminants feed is not a sufficient choice to increase AA flow at the duodenum,

Table 5 Effects of rumen-protected methionine supplements on the synthesis of microbial crude protein, production of $\mathrm{NH}_{3}-\mathrm{N}$ and $\mathrm{pH}$ using a rumen simulation technique $(\mathrm{n}=4)$

\begin{tabular}{|c|c|c|c|c|c|c|}
\hline \multirow[t]{2}{*}{ Items } & \multicolumn{4}{|c|}{ Treatments } & \multirow[t]{2}{*}{ SEM } & \multirow[t]{2}{*}{ P-value } \\
\hline & HP & LP & LPLMet & LPHMet & & \\
\hline pH before feeding* & 6.65 & 6.67 & 6.66 & 6.68 & 0.01 & 0.83 \\
\hline $\mathrm{pH}$ after feeding $(0-24 \mathrm{~h})^{*}$ & 6.68 & 6.70 & 6.73 & 6.73 & 0.01 & 0.20 \\
\hline $\mathrm{MCP}(\mathrm{mg} / \mathrm{mL})$ & $3.18^{\mathrm{a}}$ & $2.45^{b}$ & $2.62^{a b}$ & $3.10^{\mathrm{a}}$ & 0.11 & 0.01 \\
\hline $\mathrm{NH}_{3}-\mathrm{N}(\mathrm{mg} / 100 \mathrm{~mL})$ & $18.43^{\mathrm{a}}$ & $13.09^{b}$ & $13.39^{b}$ & $13.58^{b}$ & 0.80 & 0.02 \\
\hline
\end{tabular}

$\mathrm{MCP}$, microbial crude protein; $\mathrm{NH}_{3}-\mathrm{N}$, ammonia nitrogen; $\mathrm{SEM}$, standard error of mean

a,b Superscripts values within the same row, are significantly different at $(P<0.05)$

* The $\mathrm{pH}$ values have published an article of the same first author

Table 6 Effects of supplementation of RPMet with low CP on daily production and composition of gases using a RUSITEC technique $(n=4)$

\begin{tabular}{|c|c|c|c|c|c|c|}
\hline \multirow[t]{2}{*}{ Items } & \multicolumn{4}{|c|}{ Treatments } & \multirow[t]{2}{*}{ SEM } & \multirow[t]{2}{*}{ P-value } \\
\hline & $\mathrm{HP}$ & LP & LPLMet & LPHMet & & \\
\hline $\begin{array}{l}\text { Total gas production (mL/ } \\
\text { day) }\end{array}$ & $1435.75^{\mathrm{a}}$ & $1390.75^{b}$ & $1381.25^{b}$ & $1377.00^{b}$ & 7.06 & $<0.01$ \\
\hline \multicolumn{7}{|c|}{ Individual gas production (mL/day) } \\
\hline Hydrogen & 4.88 & 3.65 & 3.80 & 4.10 & 0.25 & 0.31 \\
\hline Methane & $302.47^{a}$ & $200.65^{b}$ & $205.29^{b}$ & $211.54^{b}$ & 11.83 & $<0.01$ \\
\hline Carbon dioxide & 752.37 & 621.35 & 644.73 & 684.06 & 21.31 & 0.13 \\
\hline
\end{tabular}

SEM, standard error of mean

a,b Superscripts values within the same row, are significantly different at $(P<0.05)$ 
Table 7 Effects of experimental treatments on 16S rDNA gene copy numbers of three predominant ruminal and total bacteria from solid fractions using a RUSITEC $(n=4)$

\begin{tabular}{|c|c|c|c|c|c|c|}
\hline \multirow[t]{2}{*}{ Items } & \multicolumn{4}{|c|}{ Treatments } & \multirow[t]{2}{*}{ SEM } & \multirow[t]{2}{*}{ P-value } \\
\hline & $\mathrm{HP}$ & LP & LPLMet & LPHMet & & \\
\hline \multicolumn{7}{|c|}{ Solid fraction, $\log _{10}$ of $16 \mathrm{~S}$ rDNA gene copy numbers per milliliter solid extracted liquid } \\
\hline Total bacteria & 11.79 & 10.43 & 10.93 & 11.90 & 0.35 & 0.45 \\
\hline F. succinogenes & 8.31 & 6.99 & 7.82 & 8.52 & 0.27 & 0.20 \\
\hline R. albus & $7.14^{\mathrm{a}}$ & $5.96^{b}$ & $6.57^{\mathrm{ab}}$ & $7.17^{\mathrm{a}}$ & 0.16 & $<0.01$ \\
\hline R. flavefaciens & 7.38 & 5.95 & 6.21 & 7.43 & 0.32 & 0.23 \\
\hline \multicolumn{7}{|c|}{ Liquid fraction, $\log 10$ of $16 \mathrm{~S}$ rDNA gene copy numbers per milliliter fermenter liquid } \\
\hline Total bacteria & 9.83 & 8.44 & 9.00 & 10.04 & 0.33 & 0.30 \\
\hline F. succinogenes & 6.23 & 5.74 & 5.99 & 6.73 & 0.17 & 0.18 \\
\hline R. albus & $6.13^{\mathrm{ab}}$ & $5.12 b$ & $5.40^{\mathrm{ab}}$ & $6.21^{\mathrm{a}}$ & 0.17 & 0.02 \\
\hline R. flavefaciens & 5.31 & 4.40 & 4.71 & 5.71 & 0.28 & 0.40 \\
\hline
\end{tabular}

SEM, standard error of mean

$\mathrm{a}, \mathrm{b}$ Superscripts values within the same row, are significantly different at $(P<0.05)$

because rumen atmosphere quickly degraded free AA (Volden et al. 1998). Rumen simulation is an advanced technique (RUSITEC) which simulate the condition of rumen in the laboratory circumstances under the strict control of saliva infusion, amount of feed, time of feeding, temperature, with allowing for measurement of rumen fermentation end products (Kajikawa et al. 2003). The present study is designed to measure which concentration of RPMet with low CP, reduce gases production and improve nutrients metabolism for further application in vivo study. To satisfy the maximum flow of AA in the small intestine to maintain dairy performance and also solve environmental problems related to high protein feeding in ruminant's industry. The present study reported that the disappearance of $\mathrm{CP}$ was similar in supplement groups with LP and potentially higher than HP. However, the disappearance of NDF and GE were similar among LPHMet and HP group, while, LPLMet values were noted to be similar to the LP group. Based on a meta-analysis of Leonardi and Stevenson Armentano (2003) who reported that there were no differences in DMI either in low or high CP supplemented with RPMet. Also, Trinacty et al. (2009) noted that DMI ( $\mathrm{kg} \mathrm{DM} /$ day) of diets supplemented with RPMet was significantly higher than other diets. Noftsger et al. (2005) described that supplementation with RPMet to dairy cows improved the rumen fiber digestion and VFA production. Animals fed with high forage and maize-based ration balanced with RPMet either alone or in combination showed an increased digestibility of CP (Gajera et al. 2013). However, VFA production in the rumen did not depend only on the utilization rate but also depend on substrates, fiber degradation, bacterial populations and different sections of the reticulorumen (Bannink et al. 2006). The present study showed that the production of individual and total VFA from LPHMet diet was similar to HP group during $48 \mathrm{~h}$ incubation period. As previously discussed by Noftsger et al. (2005), the supplement of RPMet sources to the rumen had effects on rumen fermentation index (VFA, $\mathrm{NH}_{3}-\mathrm{N}$ ). VanZijderveld et al. (2010) noted that VFA produced in the rumen by microbiological activity which degrades the cellulose and hemicellulose. However, Mulligan et al. (2002) reported that total and acetate VFA production associated with NDF degradability. In the current study, total gas and methane production were significantly decreased in RPMet supplementation groups. Raghavendra et al. (2007) and Yang et al. (2016) discussed that methane production depends on the fermentation of substrate, methanogens, ciliate protozoa, and hydrogenosomes, utilization of hydrogen, decline $\mathrm{H}_{2}$ production conversely decreasing $\mathrm{CH}_{4}$ production in the rumen. Furthermore, Kittelmann et al. (2014) who noticed the stronger associations between methane emissions and high population of $\mathrm{H}_{2}$ producing bacteria in sheep. Bannink et al. (2011) stated that the formation of VFA is followed by production of hydrogen gas and methanogenic archaea reduce $\mathrm{CO}_{2}$ and use $\mathrm{H}_{2}$ as a substrate for formation of propionate which decreases the overall $\mathrm{CH}_{4}$ production. Low $\mathrm{CP}$ supplemented with high methionine concentration promotes the synthesis of MCP which was similar to the HP group. The result of the present study corroborated with the findings of earlier studies. Reynolds and Kristensen (2008) concluded that overfeeding of protein in ruminant's because problems, microbes or animal goes in the catabolism of protein or AA result in the conversion of the excess nitrogen, thus feeding low CP diet is 
appropriate to approach for MCP synthesis. In line with the study of VanSoest (1994) who discussed that MCP outflow improved in rumen when levels of structural fiber and NDF content of the ration passage increased because of microbes attached to fibrous particles. Wang et al. (2016) reported that the rate and extent of CP degradation and propionate production play a significant role in the MCP synthesis in the rumen. In the current study, ruminal $\mathrm{NH}_{3}-\mathrm{N}$ of LPLMet and LPHMet treatments was similar to the value of LP and ideal range for maximal MCP synthesis. Cole et al. (2005) and Todd et al. (2013) discussed that dietary intake and digestibility of $\mathrm{CP}$ influence $\mathrm{NH}_{3}-\mathrm{N}$ emissions by affecting $\mathrm{N}$ excretion. Furthermore, these results supported our findings according to Preston and Leng (1987), optimal ruminal $\mathrm{NH}_{3}-\mathrm{N}$ for efficient digestion was recorded 5.0 to $25.0 \mathrm{mg} / \mathrm{dL}$. While, Weakley et al. (1983) reported that ruminal $\mathrm{NH}_{3}-\mathrm{N}$ from 9.34 to $11.23 \mathrm{mg} / \mathrm{dL}$ is acceptable for rumen bacterial metabolism and growth. In the current study, during simulation duration, the $\mathrm{pH}$ values observed unaffected before feeding or after feeding on 0 to $24 \mathrm{~h}$ in overall groups. As described in the previous studies by Calsamiglia et al. (2012), rumen utilizes different buffers and alkalizers and $\mathrm{pH}$ was recorded from 5.6 to 6.8. Furthermore, Russell and Wilson (1996) noted that ruminal $\mathrm{pH}$ ranges from 6.58 to 6.74 are suitable for the growth of cellulolytic bacteria in the rumen environment. Silva et al. (2016) reported that dietary CP levels did not affect ruminal $\mathrm{pH}$ in finishing beef cattle. Abbasi et al. (2018b) noted that different levels of RPMet with low CP could not significantly alter rumen $\mathrm{pH}$ before or after feeding. Furthermore, cellulose is the primary building component of plant matter microorganisms recycling them under anaerobic environment and extract energy (Vodovnik and Marinsek 2010). In the present study, the total bacterial population size of $16 \mathrm{~S}$ rDNA gene copy numbers was found similar among all groups. The main cellulolytic spp. 16S rDNA copy numbers of; $R$. flavefaciens, and $F$. succinogenes were unaffected among all groups, but $R$. album population was found lower in LP than other groups. Previous studies noted that secondary metabolites of some ingredients enhance the growth of certain species of rumen microbes (Kim et al. 2014). Further, our findings agree with (Martin et al. 2013) who stated that rations which balanced for essential AA especially RPMet either alone or in combination increase significantly the production of fibrinolytic bacterial (R. flavefaciens, F. succinogenes, and R. albus) abundance. Furthermore, Yang et al. (2016) $\mathrm{n}$ that the main cellulolytic species $R$. albus, $R$. flavefaciens and F. succinogenes were not affected by dietary CP levels in lamb's study. While, Russell and Wilson
(1996) discussed that main cellulolytic species grow on cellulose, hemicellulose, pectin and growth depend on the production of is acids, fermentation products (acetate, butyrate, hydrogen and carbon dioxide). From the previous results, it was clear that the key role of RPMet supplementation to low protein diet on rumen fermentation characteristics is attributed to its indirect effect on the alteration of the ruminal environment that can significantly decrease rumen ammonia- $\mathrm{N}$ concentration which suggests that RPMet can promote ammonia utilization in the rumen. This result may be because RPMet supplementation can enhance rumen microbial growth and the microbes can reutilize degraded ammonia- $\mathrm{N}$ to synthesize microbial proteins (Or-Rashid et al. 2001). Also, dietary RPMet supplementation leads to high RUP:RDP ratio which in turn improves the healthy condition of the rumen. The indirect effect of RPMet could enhance the growth and multiplication of cellulytic microbes for efficient DM digestion, production of volatile fatty acids and stimulation of microbial protein synthesis. Improvement of these parameters had a positive impact on productive and reproductive performance, feed cost as well asenvironmental pollution.

Menchu (2019) concluded that $N$-acetyl-L-methionine and $N$-acetyl-L-lysine have potential to provide rumen protection; and determining the optimum dosages will help to increase the benefit of these products. There also appears to be potential to increase rumen fermentation products, which is important for maintaining high milk production in dairy cows.

The dietary supplementation of RPMet at a level of $(0.11 \mathrm{~g} / \mathrm{kg})$ the most of the studied parameters was unaffected at RUSITEC. At a level of $(0.81 \mathrm{~g} / \mathrm{kg})$ inclusion, the MCP, short chain fatty acids, CP, NDF, GE, and $R$. albus population were improved. Furthermore, the production volume of total and methane gas was lower in supplement groups. In future, it should be emphasized the promising RPMet level to be tested in vivo study to evaluate effects on the flow of AA as MP at the small intestine with productive and reproduction performance, co-occurrence patterns of the microbiome in the rumen, which shines new light on fermentation, their interaction, and gases emission.

\section{Abbreviations}

AA: amino acids; ADF: acid detergent fiber; CP: crude protein; GE: gross energy; RPMet: rumen-protected methionine; HP: high protein diet (163.39 g/kg CP) without RPMet; LP: low protein diet (146.33 g/kg CP) without RPMet; LPHMet: low protein diet, supplement with high RPMet (RPMet: $0.81 \mathrm{~g} / \mathrm{kg}$ ); LPLMet: low protein diet, supplement with low RPMet (RPMet: $0.11 \mathrm{~g} / \mathrm{kg}$ ); MCP: microbial

crude protein; MP: metabolizable protein; NDF: neutral detergent fiber; NH3-N: ammonia-N; NRC: National Research Council; RDP: rumen degradable protein; RUP: rumen undegradable protein; RUSITEC: rumen simulation technique; VFA: volatile fatty acid. 


\section{Acknowledgements}

We extend our appreciation to our Institutes and Universities.

\section{Authors' contributions}

IHRA and YC designed the study, collected literature, performed the experiment, analyzed the data, wrote the paper, and drafted the manuscript. BMB and MAEM helped during collection of rumen inoculum. FA and LL contributed to lab analysis. MAA and AAS reviewed and revised the manuscript and performed the final check. All authors read and approved the final manuscript.

\section{Funding}

This work was partially supported by the National Key Research and Development Program of China (Award Numbers: 2018YFD0501600 and 2017YFD0500500), National Natural Science Foundation of China (Award Numbers: 31472122 and 31672451$)$.

\section{Availability of data and materials}

Not applicable.

\section{Ethics approval and consent to participate}

The study was conducted in accordance with the Declaration of the Local Experimental Animal Care Committee, and the protocol was approved by the ethics of the institutional committee of the College of Animal Science and Technology, Northwest A\&F University, Yangling, Shaanxi, China.

\section{Consent for publication}

Not applicable.

\section{Competing interests}

The authors declare that they have no competing interests.

\section{Author details \\ ${ }^{1}$ College of Animal Science and Technology, Northwest A\&F University, Yangling, Shaanxi, China. ${ }^{2}$ Department of Animal Nutrition, Faculty of Animal Production and Technology, Cholistan University of Veterinary and Animal Sci- ences, Bahawalpur, Punjab, Pakistan. ${ }^{3}$ School of Life Science and Engineering, Southwest University of Science and Technology, Mianyang, Sichuan, China. ${ }^{4}$ Department of Nutrition and Veterinary Clinical Nutrition, Faculty of Veteri- nary Medicine, Damanhour University, Damanhour 22511, Egypt. ${ }^{5}$ Depart- ment of Theriogenology, Faculty of Veterinary Medicine, Zagazig University, Zagazig 44519, Egypt.}

Received: 9 April 2019 Accepted: 15 June 2019

Published online: 26 June 2019

\section{References}

Abbasi IHR, Abbasi F, Soomro RN, Abd El-Hack EM, Abdel-Latif AM, Li W, Hao R, Sun F, Bondinga BM, Hayat K, Yao J, Cao Y (2017) Considering choline as methionine precursor, lipoproteins transporter, hepatic promoter and antioxidant agent in dairy cows. AMB Express 7:214

Abbasi IHR, Abbasi F, Abd El-Hack EM, Abdel-Latif AM, Soomro RN, Hayat K, Mohamed MAE, Bondinga BM, Yao J, Cao Y (2018a) Critical analysis of excessive utilization of crude protein in ruminants ration: impact on environmental ecosystem and opportunities of supplementation of limiting amino acids. Environ Sci Pollut Res 25:181-190

Abbasi IHR, Abbasi F, Abd El-Hack EM, Swelum AA, Yao J, Cao Y (2018b) Postruminal effects of rumen-protected methionine supplementation with low protein diet using long-term simulation and in vitro digestibility technique. AMB Express 8:36

Bannink A, Kogut J, Dijkstra J, France J, Kebreab E, Van Vuuren AM, Tamminga S (2006) Estimation of the stoichiometry of volatile fatty acid production in the rumen of lactating cows. J Theor Biol 238:6-51

Bannink A, Van Schijndel MW, Dijkstra J (2011) A model of enteric fermentation in dairy cows to estimate methane emission for the Dutch national inventory report using the IPCC Tier 3 approach. J Anim Feed Sci Technol 166:603-618

Calsamiglia S, Blanch M, Ferret A, Moya D (2012) Issubacute ruminal acidosis a pH related problem?. Causes and tools for its control. J Anim Feed Sci Technol 172:42-50
Cole NA, Clark RN, Todd RW, Richardson CR, Gueye A, Greene LW, Bride KM (2005) Influence of dietary crude protein concentration and source on potential ammonia emissions from beef cattle manure. J Anim Sci 83:722-731

Faciola AP, Broderick GA (2014) Effects of feeding lauric acid or coconut oil on ruminal protozoa numbers, fermentation pattern, digestion, omasal nutrient flow and milk production in dairy cows. J Dairy Sci 97:5088-5100

Gajera AP, Dutta KS, Savsani HH, Parsana DK, Vataliya PH, Sipai SH, Ribadiya NK (2013) Effect of rumen-protected lysine, methionine and fat on nutrients utilization in growing Jaffrabadi heifers. Indian J Anim Nutr 30:351-357

Guyader J, Doreau M, Morgavi DP, Gerard C, Loncke C, Martin C (2016) Longterm effect of linseed plus nitrate fed to dairy cows on enteric methane emission and nitrate and nitrite residuals in milk. Animal 10:1173-1181

Kajikawa H, Jin H, Terada F, Suga T (2003) Operation and characteristics of newly improved and marketable artificial rumen (Rusitec), vol 2, National Institute of livestock and grassland science, Tsukuba, Ibaraki (Japan), pp $1-30$

Kim WY, Hanigan MD, Lee SJ, Lee SM, Kim DH, Hyun JH, Yeo JM, Lee SS (2014) Effects of Cordyceps militaris on the growth of rumen microorganisms and in vitro rumen fermentation with respect to methane emissions. J Dairy Sci 97:7065-7075

Kittelmann S, Pinarespatino CS, Seedorf H, Kirk MR, Ganesh S, McEwan JC (2014) Two different bacterial community types are linked with the lowmethane emission trait in sheep. PLoS ONE 9(7):103-171

Koike S, Kobayashi Y (2001) Development and use of competitive PCR assays for the rumen cellulolytic bacteria: Fibrobacter succinogenes, Ruminococcus albus and Ruminococcus flavefaciens. FEMS Microbiol Lett 204:361-366

Kumar MS, Kaur G, Sandhu AK (2014) Genomic DNA isolation from fungi, algae, plant, bacteria and human blood using CTAB. Int J Sci Res 3:617-618

Lambert JL, Zitomer F (1960) Differential colorimetric determination of nitrite and nitrate ions. Anal Chem 32:1684-1686

Leonardi CM, Stevenson Armentano LE (2003) Effect of two levels of crude protein and methionine supplementation on performance of dairy cows. J Dairy Sci 86:4033-4042

Liu L, Xu X, Cao Y, Cai C, Cui H, Yao J (2017) Nitrate decrease methane production also by increasing methane oxidation through stimulating NC10 population in ruminal culture. AMB Express 7:76

Martin C, Mirande C, Morgavi DP, Forano E, Devillard E, Mosoni P (2013) Methionine analogues $\mathrm{HMB}$ and $\mathrm{HMBi}$ increase the abundance of cellulolytic bacterial representatives in the rumen of cattle with no direct effects on fiber degradation. Anim Feed Sci Technol 182:16-24

McDougall E (1948) Studies on ruminant saliva. I. The composition and output of sheep's saliva. Biochem J 43(1):99-109

Menchu S (2019) Ruminal protection and intestinal availability of rumenprotected methionine and lysine in lactating dairy cows. Master thesis, Department: Animal, Dairy, and Veterinary Sciences Utah State University, Logan, Utah

Mulligan FJ, Caffrey PJ, RathM Callan JJ, Brophy PO, Mara FP (2002) An investigation of feeding level effects on digestibility in cattle for diets based on grass silage and high fiber concentrates at two forages: concentrate ratios. Livest Sci 77:311-323

National Research Council (2001) Nutrient requirements of dairy cattle, 7th edn. National Academies Press, Washington, DC

Noftsger S, St-Pierre NR, Sylvester JT (2005) Determination of rumen degradability and ruminal effects of three sources of methionine in lactating cows. J Dairy Sci 88:223-237

Or-Rashid M, Onodera R, Wadud S (2001) Biosynthesis of methionine from homocysteine, cystathionine and homoserine plus cysteine by mixed rumen microorganisms in vitro. Appl Microbiol Biotechnol 55(6):758-764.

Preston TR, Leng RA (1987) Matching ruminant production systems with available resources in the tropics and sub-tropics. Penambull Book, Armidale

Raghavendra B, Tajima K, Takusari N, Higuchi K, Enishi O, Kurihara M (2007) Comparison of in vivo and in vitro techniques for methane production from ruminant diets. Asian-Australas J Anim Sci 20(7):1049-1056

Reynolds CK, Kristensen NB (2008) Nitrogen recycling through the gut and the nitrogen economy of ruminants: an asynchronous symbiosis. J Anim Sci 86(14 Suppl):293-305

Rhoads ML, Rhoads RP, Gilbert RO, Toole R, Butler WR (2006) Determental effects of high plasma urea nitrogen levels on the viability of embryos from lactating dairy cows. Anim Reprod Sci 91:1-10 
Russell JB, Wilson DB (1996) Why are ruminal cellulolytic bacteria unable to digest cellulose at low pH. J Dairy Sci 79:1503-1509

Schwiertz A, Jacobi M, Frick JS, Richter M, Rusch K, Köhler H (2010) Microbiota in pediatric inflammatory bowel disease. J Pediatr 157:240-244

Silva LDD, Pereira OG, Silva TCD, Valadares Filho SC, Ribeiro KG (2016) Affects of silage crop and dietary crude protein levels on digestibility ruminal fermentation, nitrogen use efficiency, and performance of finishing beef cattle. Anim Feed Sci Technol 220:22-33

Sinclair KD, Garns WPC, Mann GE, Sinclair LA (2014) Reducing dietary protein in dairy cow diets: implications for nitrogen utilization, milk production, welfare, and fertility. Animal 8:262-274

Soliva C, Hess H (2007) Measuring methane emission of ruminants by in vitro and in vivo techniques. In: Makkar HPS, Vercoe PE (eds) Measuring methane production from ruminants. Springer, Dordrecht

Todd RW, Cole NA, Waldrip HM, Aiken RM (2013) Arrhenius equation for modeling feed yard ammonia emissions using temperature and diet crude protein. J Environ Qual 42:666-671

Trinacty YJ, Krizova L, Richter M, Cerny V, Riha J (2009) Effect of rumen-protected methionine, lysine or both on milk production and plasma amino acids of high-yielding dairy cows. Czech J Anim Sci 54:239-248

VanSoest PJ (1994) Nutritional ecology of the ruminant, vol 2. Cornell University Press, Ithica

VanSoest PJ, Robertson JB, Lewis BA (1991) Methods for dietary fiber, neutral detergent fiber, and non-starch polysaccharides in relation to animal nutrition. J Dairy Sci 74:3583-3597

VanZijderveld SM, Gerrits WJJ, Apajalahti JA, Newbold JR, Dijkstra J, Leng RA, Perdok HB (2010) Nitrate and sulfate: effective alternative hydrogen sinks for mitigation of ruminal methane production in sheep. J Dairy Sci 93:5856-5866

Vasconcelos JT, Greene LW, Cole NA, Brown MS, McCollum FT, Tedeschi LO (2007) Effects of phase feeding of protein on performance, blood urea nitrogen concentration, manure nitrogen: phosphorus ratio, and carcass characteristics of feedlot cattle. J Anim Sci 84:3032-3038

Vodovnik M, Marinsek LR (2010) Cellulosomes promising supramolecular machines of anaerobic cellulolytic microorganisms. Acta Chim Slov 57:767-774

Volden H, Velle WO, Harstad M, Aulie A, Sjaastad OV (1998) Apparent ruminal degradation and rumen escape of lysine, methionine, and threonine administered intraruminally in mixtures to high-yielding dairy cows. J Anim Sci 76:1232-1240

Wang C, Liu Q, Guo G, Huo WJ, Ma L, Zhang YL, Pei CX, Zhang SL, Wang H (2016) Effects of rumen-protected folic acid on ruminal fermentation, microbial enzyme activities, cellulolytic bacteria and urinary excretion of purine derivatives in growing beef steers. Anim Feed Sci Technol 221:185-194

Weakley DC, Stern MD, Satterr LD (1983) Factors affecting disappearance of feedstuffs from bags suspended in the rumen. J Anim Sci 56:493-507

Weatherburn MW (1967) Phenol-hypochlorite reaction for determination of ammonia. Anal Chem 39:971-974

Yang CT, Si BW, Diao QY, Jin H, Zeng SQ, Tu Y (2016) Rumen fermentation and bacterial communities in weaned Chahaer lambs on diets with different protein levels. J Integr Agric 15:1564-1574

Yu Z, Michel FC, Hansen G, Wittum T, Morrison M (2005) Development and application of real-time PCR assays for quantification of genes encoding tetracycline resistance. Appl Environ Microbiol 71(11):6926-6933

Zhang GJ, Xie CY, Thackerc PA, Htood JK, Qiao SY (2013) Estimation of the ideal ratio of standardized ileal digestible threonine to lysine for growing pigs (22-50 kg) fed low crude protein diets supplemented with crystalline amino acids. Anim Feed Sci Technol 18:83-91

Zhang XF, Zhang H, Wang Z, Zhang X, Zou H, Cui Tan, Peng Q (2015) Effects of dietary carbohydrate composition on rumen fermentation characteristics and microbial population in vitro. Ital J Anim Sci 14(3):3366

Zhao XH, Zhang T, Xu M, Yao JH (2010) Effects of physically effective fiber on chewing activity, ruminal fermentation, and digestibility in goats. J Anim Sci 89:501-509

Zhao X, Liu C, Liu Y, Li C, Yao JH (2013) Effects of replacing dietary starch with neutral detergent soluble fiber on ruminal fermentation, microbial synthesis and populations of ruminal cellulolytic bacteria using the rumen simulation technique (Rusitec). J Anim Physiol 9(7):1161-1169

\section{Publisher's Note}

Springer Nature remains neutral with regard to jurisdictional claims in published maps and institutional affiliations.

\section{Submit your manuscript to a SpringerOpen ${ }^{\circ}$ journal and benefit from:}

- Convenient online submission

- Rigorous peer review

- Open access: articles freely available online

- High visibility within the field

- Retaining the copyright to your article

Submit your next manuscript at springeropen.com 